\title{
Gill tissue reactions in walleye Stizostedion vitreum vitreum and common carp Cyprinus carpio to glochidia of the freshwater mussel Lampsilis radiata siliquoidea
}

\author{
D. L. Waller ${ }^{1}$, L. G. Mitchell ${ }^{2}$ \\ ${ }^{1}$ U.S. Fish and Wildlife Service, National Fisheries Research Center, PO Box 818, La Crosse, Wisconsin 54602, USA \\ ${ }^{2}$ Department of Zoology and Animal Ecology, Iowa State University, Ames, Iowa 50011, USA
}

\begin{abstract}
The glochidia of many freshwater mussels, which are obligate parasites on the gills, fins, and other body parts of specific fishes, attach to a suitable host, become encapsulated, and develop to the free-living juvenile stage. Using light and electron microscopy we compared gill tissue reactions in a suitable host (walleye Stizostedion vitreum vitreum) and unsuitable host (common carp Cyprinus carpio) infected with Lampsilis radiata siliquoidea. Encapsulation of glochidia on walleye gills was completed by 6 h post-infection at 20 to $22^{\circ} \mathrm{C}$. Capsular formation and compaction were accompanied by a general increase in epithelioid cells. Fibrotic material appeared in capsules at about $48 \mathrm{~h}$ and virtually filled capsular cells from about Day 5 to Day 11 post-infection. Liberation of juvenile mussels was accompanied by thinning of the capsule from about Day 11 to Day 17. Although glochidia attached to the gills of common carp, few became encapsulated. By $48 \mathrm{~h}$ post-infection, preliminary capsular growth was evident and necrotic cells and cellular debris appeared at the edges of the growth. However, all glochidia were sloughed from carp gills by $60 \mathrm{~h}$. Host specificity of L. radiata siliquoidea apparently depended on a combination of the attachment response of glochidia, differences in the encapsulation process, and tissue reactions in the fish.
\end{abstract}

\section{INTRODUCTION}

A critical stage in the development of many freshwater mussels is an obligatory parasitic period spent on fish. Glochidia attach most commonly to the gills or fins, become encapsulated, and develop to the juvenile stage. Early investigators showed that the glochidia of a mussel species are specific for certain host fishes. If they are not attached to a suitable host, they are sloughed off before metamorphosis is complete (Arey 1932a). Several mechanisms have been offered to explain the host specificity of freshwater mussels: glochidia may attach only to certain host species: glochidia may reject a fish because it lacks a specific chemical cue; and glochidia may be rejected by the immune system of the fish.

Using light and electron microscopy, we examined the development of tissue capsules surrounding glochidia of the fat mucket Lampsilis radiata siliquoidea, an historically common mussel of the upper
Mississippi River and its major tributaries. The glochidia of this species are hookless and are primarily gill parasites that show virtually no increase in size while on the host fish. The encapsulation process was studied after laboratory infection of a suitable host species, walleye Stizostedion vitreum vitreum, and a resistant species, common carp Cyprinus carpio. This is the first report of ultrastructural events in glochidial encapsulation.

\section{MATERIALS AND METHODS}

Females of Lampsilis radiata siliquoidea were obtained from the upper Mississippi River at La Crosse, Wisconsin, USA. Glochidia were removed from the marsupia by flushing with water injected with a hypodermic needle and syringe. The maturity of glochidia was determined by placing a subsample in a weak saline solution; 99 to $100 \%$ glochidia responded 
by snapping the valve shut indicating they were fully mature. Young-of-the-year walleye (average total length $70 \mathrm{~mm}$ ) and common carp (average total length $40 \mathrm{~mm}$ ), were obtained from the National Fisheries Research Center, La Crosse, Wisconsin. Fish were hatchery-reared and had not previously been exposed to glochidia. Two separate infection trials were run for each species. The fish were infected individually by pipetting a one drop suspension (200 to 1000 glochidia) into the right branchial cavity. Each species was held separately in $38 \mathrm{l}$ flow-through aquaria at 18 to $22^{\circ} \mathrm{C}$ and fed frozen brine shrimp and commercial trout food twice daily. Control fish were held separately under the same conditions. Three common carp and 2 walleyes were sacrificed at each sampling period, and the right giiis were removed for sectioning. Fisin of both species were sampled at $0,2,4,6,12,24$, and $48 \mathrm{~h}$ postinfection, and walleyes at $5,8,11,14$, and $17 \mathrm{~d}$ postinfection. Three control fish of each species were taken at $6 \mathrm{~h}$ post-infection in Trial 1, and 3 common carp at $12 \mathrm{~h}$ and 3 walleyes at $20 \mathrm{~d}$ in Trial 2. Observations were also made of uninfected gill tissue of the experimental fishes.

Gill tissues for paraffin sectioning were fixed in Bouin's fluid overnight, washed in $70 \%$ ethanol and dehydrated through a graded ethanol series, cleared in xylene, and embedded in paraffin. Sections of 6 to $7 \mu \mathrm{m}$ were stained with hematoxylin and eosin. Two branchial arches from each fish were serially sectioned.

For transmission electron microscopy, tissue samples were fixed overnight in cold $2.5 \%$ glutaraldehyde and $2 \%$ paraformaldehyde solution (Karnovsky's fixative) and then washed for $1 \mathrm{~h}$ in $0.1 \mathrm{M}$ sodium cacodylate buffer ( $\mathrm{pH} 7.2,2 \mathrm{mM}$ calcium chloride, $5.5 \%$ sucrose). The first set of samples was then decalcified in $10 \%$ EDTA for $30 \mathrm{~min}$; however, because the EDTA treatment did not substantially alter the hardness of the glochidial. shell, we eliminated this step from later samples. Tissues were postfixed for $1 \mathrm{~h}$ in $1 \%$ osmium tetroxide in sodium cacodylate buffer, washed in buffer for $1 \mathrm{~h}$ and dehydrated in a graded acetone series. Material was embedded in Medcasts ${ }^{(B)}$ epoxy resin over a period of $2 \mathrm{~d}$, and sectioned on an LKB ultramicrotome with a diamond knife. Semi-thin sections $(0.5$ $\mu \mathrm{m}$ ) were stained with warm $1 \%$ toluidine blue in borax for light microscopy. Ultrathin sections (50 nm) were mounted on formvar coated grids, stained with uranyl acetate and lead citrate and examined in a Hitachi HUIIE transmission electron microscope at $50 \mathrm{kV}$.

The ultrastructural study emphasized early cytological changes; at each sampling period, we examined 4

\footnotetext{
8. Mention of trade names or manufacturers does not imply U.S. Government endorsement of commercial products
}

to 14 glochidial capsules from 3 to 8 different fish. Measurements of tissue and cell structures were made from micrographs and are provided as a general reference to their relative sizes. Cells of the gills were identified from the accounts of Newstead (1967) and Laurent \& Dunel (1980). Leukocytes were identified according to Weinreb (1963), Lester \& Desser (1975), Ferguson (1976), and Cannon et al. (1980).

\section{RESULTS}

\section{Normal gill tissue in walleye}

The structure of uninfected walleye gill tissue was similar to that of other species of teieosis as ciescribed by Newstead (1967). Pillar cells supported the lamellar blood space. A basal lamina covered the pillar cells and a double layer of epithelial cells covered lamellar surfaces (Fig. 1).

\section{Infected walleye gill tissue}

$\mathbf{0}$ to $2 \mathrm{~h}$ post-infection. Of 66 glochidia studied in tissue sections, $6(9 \%)$ were attached to gill rakers; the other $60(91 \%)$ were attached to filament tips and along the length of 1 or 2 filaments. Closure of the shell on gill tissue compressed and distorted the structure of a filament, occluded the blood spaces, and blocked circulation in to the tissue held by the glochidium (Fig. 2). Epithelial cell hyperplasia was evident on Iamellae, and some affected lamellae also had 2 to 3 times more chloride cells than normal. These changes were most pronounced on lamellae adjacent to glochidia. By $2 \mathrm{~h}$ post-infection, most glochidia were contained in a capsule 1 to $18 \mu \mathrm{m}$ thick, consisting of 1 to 4 cell layers; epithelial cell proliferation was evident along the entire length of some infected filaments.

As seen with the electron microscope, cells adjacent to the glochidial bite were elongate and pseudopodic, and lacked well-defined membranous cell organelles at $2 \mathrm{~h}$ post-infection. Cellular changes were also evident in 1 to 5 lamellae adjacent in the encapsulating glochidia. Epithelial layers on these lamellae were often separated by about 3 to $4.5 \mu \mathrm{m}$, and many epithelial cells had surface blebs or stalks (Fig. 3) instead of a regular border of microridges as seen in normal tissue. In some fish, 3 to 4 times more chloride cells were present in the epithelial layer and the secondary blood space of infected than of uninfected gill tissue.

Glochidial capsules consisted mainly of chloride, epithelioid, and necrotic cells. The chloride cells in the capsule and adjacent area contained extensive vesicular endoplasmic reticula, swollen mitochondria, and 

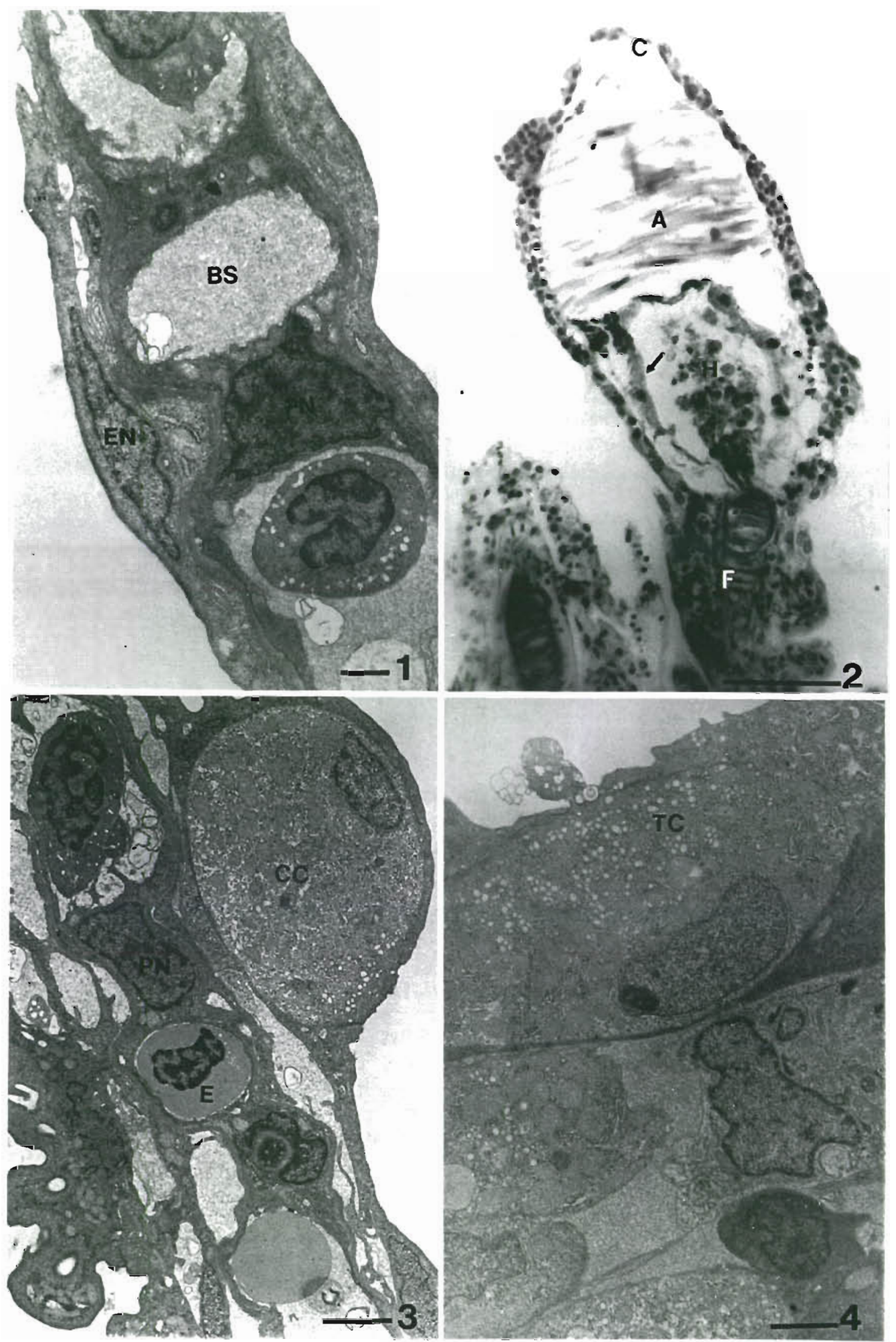

Figs. 1 to 4. Stizostedion vitreum vitreum. Sections of walleye gill. Fig. 1. Lamella of uninfected gill. Pillar cells support the lamellar blood space (BS). A basal lamina and a double layer of epithelia (EN) are external to the pillar cells (PN). EM; scale bar = $1 \mu \mathrm{m}$. Fig. 2. Glochidium attached at the tip of the lamellae surrounded by a thin capsule (C). Material (H) between the mantle (arrow) is filament tissue $(F)$ enclosed by the valves during attachment. A: glochidial adductor muscle. $\mathrm{H} \& \mathrm{E}$; scale bar $=50 \mu \mathrm{m}$. Fig. 3. Epithelial layers are separated and some cells are pseudopodic at $2 \mathrm{~h}$ post-infection. A chloride cell (CC) is located on the outer epithelium. PN: pillar cell; E: erythrocyte. EM; scale bar $=2 \mu \mathrm{m}$. Fig. 4 . Outer capsule layer at $2 \mathrm{~h}$ post-infection. Note the swollen mitochondria and endoplasmic reticular of the transformed cells (TC). EM; scale bar $=2 \mu \mathrm{m}$ 
nuclei with sparse areas of dense chromatin (Fig. 4). These abnormal chloride cells are hereinafter referred to as transformed cells. Necrotic cells had an indistinct nucleoplasm and sparse cytoplasm, and some lacked a plasmalemma. Inner cell layers, which typically were tightly compacted around the glochidial periostracum, consisted mainly of elongate pseudopodic epithelioid cells with a homogeneous nucleoplasm and cytoplasm with few membranous organelles. Basal laminae and pillar cells were also incorporated into some capsules. Incorporated pillar cells had reduced flanges and contained some cytoplasmic vacuoles and myelin bodies, 0.05 to $0.15 \mu \mathrm{m}$ in diameter.

4 to $6 \mathrm{~h}$ post-iniection. Cellular changes described above were more pronounced by $4 \mathrm{~h}$ post-infection. Hyperpiasia was more extensive and caused the fusion of lamellae on infected filaments and of some uninfected filaments adjacent to glochidial capsules. Ultrastructurally, transformed cells composed up to half of the cell population in many affected areas. Intercellular spaces were extensive, and membrane blebs and stalks were common on epithelial cell surfaces. By $6 \mathrm{~h}$ postinfection, all glochidia were encapsulated. Capsules (2 to $17 \mu \mathrm{m}$ thick) were irregular in outline and 1 to 7 cell layers thick; inner cells were tightly compacted. Capsular cells had interdigitating membranes; tight junctions were rare. The outer, looser layers often contained aggregates of cell debris, leukocytes, and large necrotic cells. Cells in the outermost capsular layer had microridges similar to those in normal epithelium. Intercellular spaces in capsules contained small lymphocytes and heterophils, as well as macrophages that contained myelin bodies, nuclear and cytoplasmic debris, pyknotic cells, and electron-dense circular granules $(0.7 \mu \mathrm{m}$ in diameter $)$.

12 to $48 \mathrm{~h}$ post-infection. Cellular composition of the capsule changed during this period; macrophages and epithelioid cells increased in number and transformed cells decreased. By $48 \mathrm{~h}$ post-infection, epithelioid cells with numerous right junctions were dominant in capsules. Capsules ranged in thickness from $4.0 \mu \mathrm{m}$ (3 cells thick) to about $22.5 \mu \mathrm{m}$ in areas where pillar cells were incorporated into the capsular wall. The capsule also contained loose aggregates of necrotic cells, heterophils, and erythrocytes. The PTAH stain indicated that fibrous material was present in the capsule at $48 \mathrm{~h}$, but not at $24 \mathrm{~h}$ post-infection. Electron microscopy confirmed the presence of fibrous tracts (about 0.2 to $0.3 \mathrm{um}$ wide) in epithelioid cells at $48 \mathrm{~h}$ post-infection.

$\mathbf{5} \mathrm{d}$ to $\mathbf{1 7} \mathrm{d}$ post-infection. Capsules and surrounding tissues were similar to those at $48 \mathrm{~h}$ in samples taken up to $11 \mathrm{~d}$, except that capsular epithelioid cells contained more fibrous material. By $11 \mathrm{~d}$ post-infection, capsules consisted largely of fiber-filled cells with prominent ribosomes (Fig. 5), and showed areas of thinning. By
$14 \mathrm{~d}$ post-infection, portions of all capsules were markedly thinner; some capsules had ruptured and contained a partly liberated juvenile mussel or amorphous noncellular material (Fig. 6). Sections of encapsulated juveniles showed the larval mantle had been replaced by adult mantle cells and the foot, digestive tract and gland, and rudimentary gills had developed. Fully transformed juveniles, as evidenced by the separation of the 2 adductor muscles and movement of the foot and valves, were recovered from the bottoms of aquaria from 14 to $17 \mathrm{~d}$ post-infection. Liberation of juveniles appeared to result from thinning of the capsule wall and movement of the mussels.

\section{Normal gill tissue in common carp}

The structure of the common carp gill is similar to that of the walleye. Eosinophils, similar to those described by Weinreb (1963) and Lester \& Desser (1975), were found in normal common carp tissue. Granules in these cells were either small (about $0.05 \mu \mathrm{m}$ in diameter) and contained slender electron dense rods or were large (about $0.6 \mu \mathrm{m}$ in diameter) and contained spherical granules (about $0.04 \mu \mathrm{m}$ in diameter).

\section{Infected carp gill tissue}

0 to 2 h post-infection. About equal numbers of glochiclia were located on gill filaments and gill rakers Cell and tissue changes associated with glochidial infections were similar to those in the walleye; however, evidence of glochidial encapsulation was not pronounced. The outer epithelium of infected lamellae had an irregular stalked or bulged profile and often contained large necrotic cells. Pseudopodic and transformed cells were found in the vicinity of glochidia.

4 to 6 h post-infection. Of 21 glochidia found in these samples, only 5 were on filaments; all others were on gill rakers. Some filaments had lamellar gaps, apparently representing sites from which glochidia had been sloughed. Filament tissue surrounding the gaps contained necrotic cells, and adjacent filaments were markedly hyperplastic (Fig. 7). Glochidia on filaments and rakers were partly encapsulated, but the capsules were generally different from those on the walleye. An inner space ( 3 to $5 \mu \mathrm{m}$ ) between cells of the capsule and the glochidial periostraca contained necrotic cells and cellular debris. Cell layers of 10 capsules sampled contained eosinophilic granulocytes in densities of from 1 to 8 cells per $20000 \mu^{2}$ Necrotic cells and debris also appeared in the outermost layers of capsules.

12 to $60 \mathrm{~h}$ post-infection. Of 14 glochidia found on 

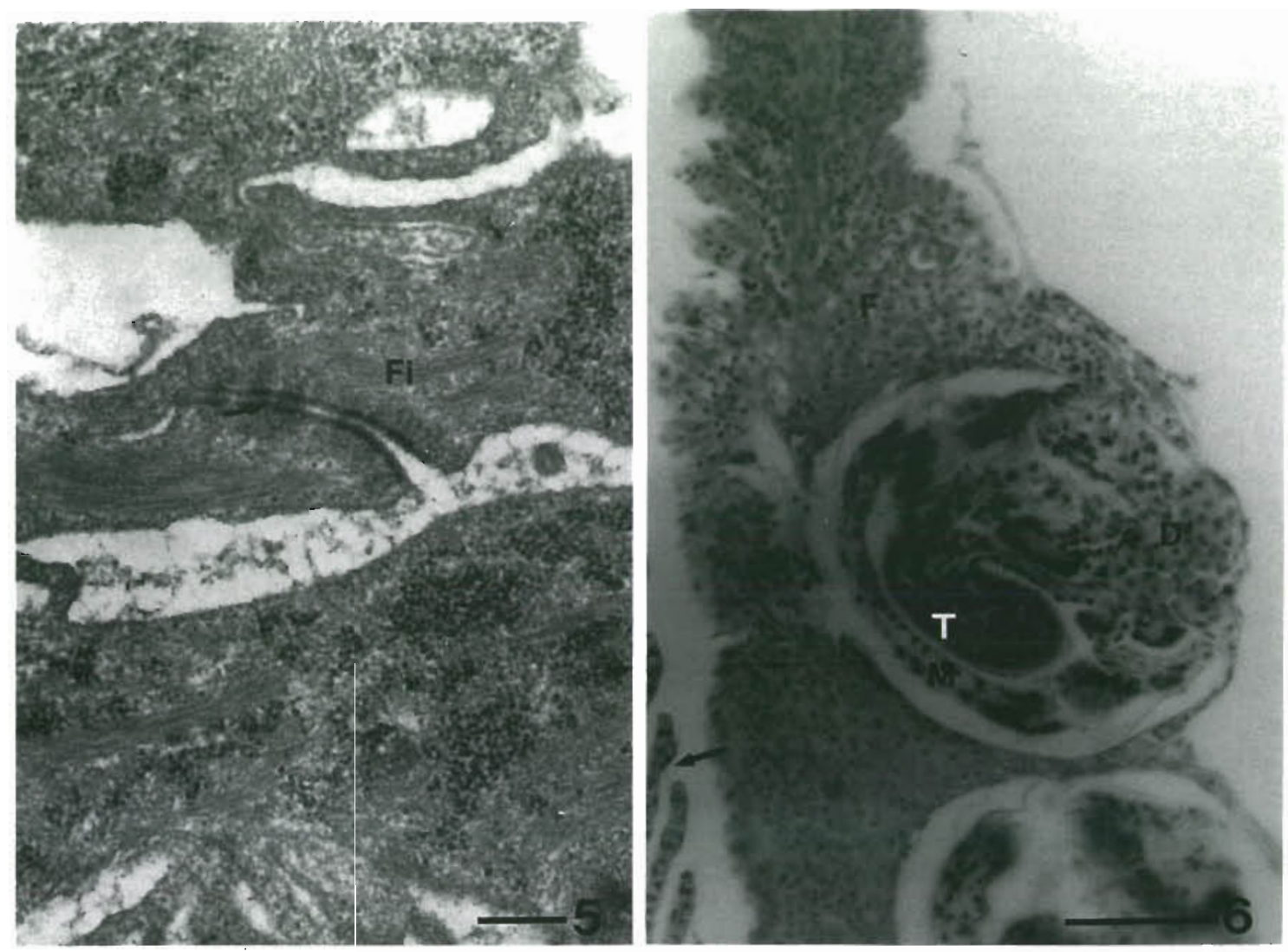

Figs. 5 to 6. Stizostedion vitreum vitreum. Sections of infected walleye gill. Fig. 5 . Cells of a capsule in an infected walleye at $11 \mathrm{~d}$ post-infection. The capsule consists of fiber-filled cells (Fi). Note the tight cell junctions between 2 capsular cells (arrow). EM, scale bar $=25 \mu \mathrm{m}$. Fig. 6 . A fully transformed juvenile at $14 \mathrm{~d}$ post-infection on a walleye. F: filament; D: digestive gland; M: definitive mantle; T: foot. A single thin cell layer remains around much of the mussel. The adjacent filament (arrow) appears normal in contrast to the hyperplastic infected filament. $\mathrm{H} \& \mathrm{E}$; scale bar $=50 \mu \mathrm{m}$
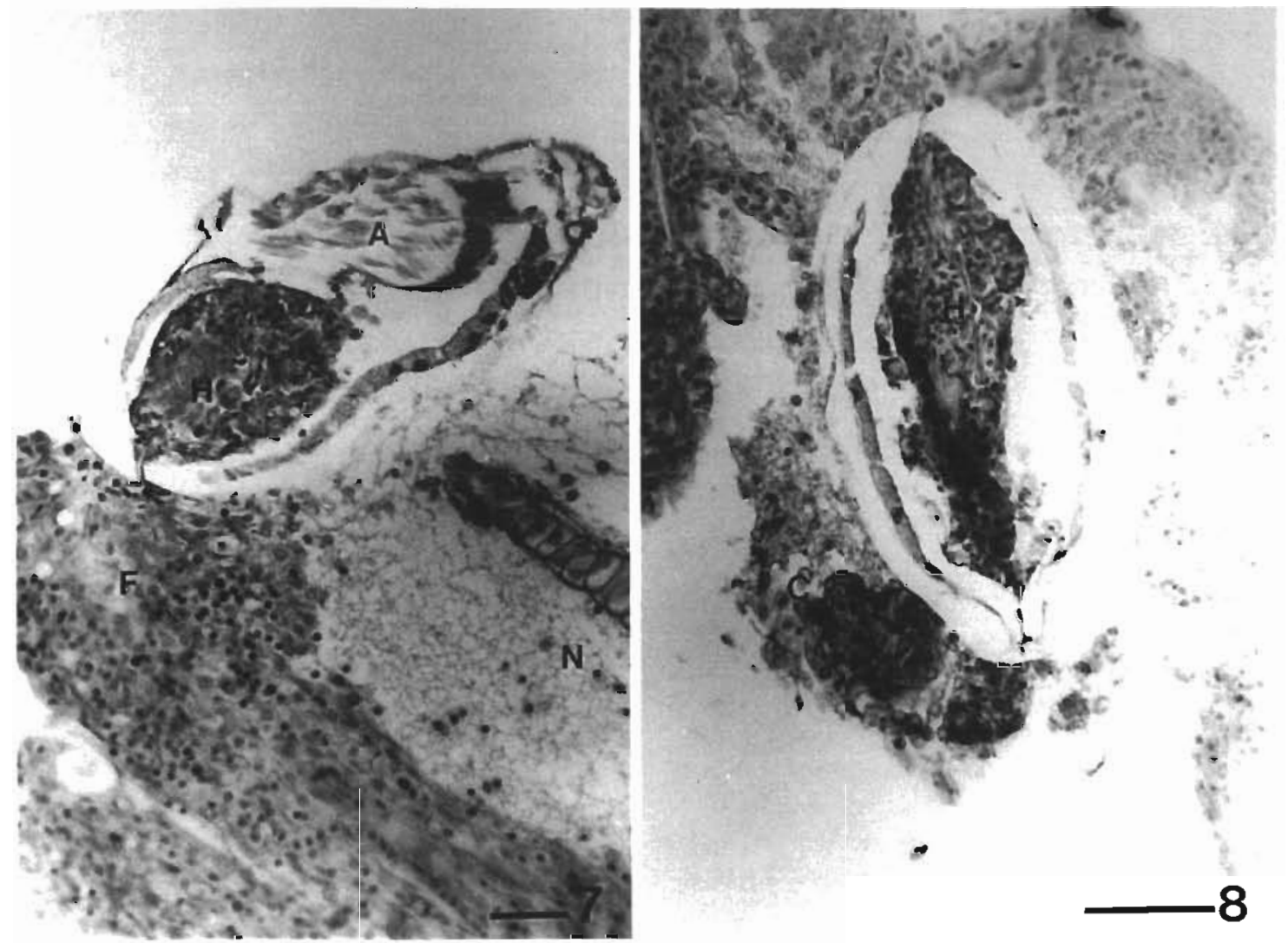

Figs. 7 and 8. Cyprinus carpio. Sections of infected common carp gill. Fig. 7. Encapsulation had not occurred at $6 \mathrm{~h}$ post-infection; it appears the glochidium will be sloughed. A: glochidial adductor muscle; F: filament; H: host tissue; $N$ : necrotic tissue. H \& $\mathrm{E}$; scale bar $=25 \mu \mathrm{m}$. Fig. 8. Partially encapsulated glochidium at $12 \mathrm{~h}$ post-infection on common carp. The capsule (C) consists of many necrotic cells and much cellular debris in contrast to that formed in walleye (see Fig. 2). $\mathrm{H}$ : host tissue. H \& $E_{;}$scale bar $=50$ um 
common carp gills from 12 to 24 h post-infection, 4 were on filaments and 10 were on rakers. In the first trial, water temperatures ranged from 18 to $19^{\circ} \mathrm{C}$, and by 48 h, only 2 carp remained infected. All glochidia were on filaments. No fish remained infected by $60 \mathrm{~h}$ postinfection. In Trial 2 (water temperature 20 to $21^{\circ} \mathrm{C}$ ) no fish remained infected by $12 \mathrm{~h}$ post-infection.

Capsule construction varied on the carp that were examined. At $12 \mathrm{~h}$ post-infection, capsules and surrounding tissues contained eosinophilic granulocytes at densities similar to those at $6 \mathrm{~h}$. Several unattached glochidia, surrounded by necrotic capsular cells, were seen between filaments in sectioned material. Capsules on 1 carp at $48 \mathrm{~h}$ were virtually identical to those on walleyes, except that the hyperplasia was more pronounced in the surrounding tissue in carp. Other glochidia found attached to carp gills during the 12 to $48 \mathrm{~h}$ period were surrounded by incomplete capsules with intermittently thin, irregular walls, and often necrotic cells and cellular debris on the outer edges (Fig. 8).

\section{DISCUSSION}

Although earlier reports attributed encapsulation to either hyperplasia or cell movements (Lefevre \& Curtis 1910, Young 1911, Arey 1932b,c), our results indicated that cell proliferation, transformation, and pseudopodial extension all contributed to capsule formation. Glochidia were initially surrounded by elongate cells, and later thickening and compaction of the capsule seemed to result from hyperplasia, cellular transformation, and cell migration. The encapsulation process in the walleye probably represented a typical progression of responses to Lampsilis glochidia in suitable hosts; that observed in carp may be typical of the responses in unsuitable hosts. Major differences were that, in the walleye, most glochidia were encapsulated on gill filaments rather than on gill rakers; capsules became progressively more compact and uniform in cell composition, with the most compact capsular cells adjacent to the mussel periostracum; fibrous material and cellto-cell junctions in the capsule increased over time. Liberation of juvenile mussels from walleyes followed thinning of the capsule wall. As suggested by Arey (1932b), thin areas of capsules may be broken by expansion of the mussels valves and protrusion of the foot. Arey also suggested that gross sloughing of capsular cells and reverse migration of cells contribute to juvenile release; we saw no evidence of these processes.

Host tissue responses to Lampsilis glochidia are less pronounced than those elicited in other fishes in response to other species of freshwater mussels. Sal- monids infected with glochidia of Margaritifera margaritifera show more extensive lamellar fusion, and this response is progressive throughout the course of infection (Karna \& Millemann 1978). This response may be associated with the nearly $600 \%$ increase in size that Margaritifera glochidia undergo while encapsulated; Lampsilis glochidia did not increase appreciably in size during the parasitic phase.

In common carp, many glochidia seemed to have been lost from gill surfaces before encapsulation occurred. Glochidia may have dropped off in response to noxious chemical factors in carp mucus. However, the appearance of lamellar gaps, necrotic and hyperplastic foci along filaments, unattached glochidia surrounded by necrotic capsular cells, and loss of all glochidia from the gills in less than $3 \mathrm{~d}$ indicates that the common carp actively rejected the glochidia of Lampsilis radiata silliquoidea. The shorter maximum attachment time observed in Trial 2 was probably due to slightly greater water temperature.

Most glochidia that remained on carp gills were surrounded by poorly formed capsules. Meyers et al. (1980) found that glochidia of Margaritifera margaritifera typically did not become completely encapsulated in coho salmon Oncorhynchus kisutch. The noncellular, necrotic inner zones of capsules in carp, pronounced hyperplasia in surrounding gill tissues, and the presence of eosinophilic granulocytes in capsules and surrounding tissues also may represent mechanisms for glochicial rejection. Fustish \& Millemann (1978) reported that coho salmon infected with glochidia of $M$. margaritifera displayed a greater degree of hyperplasia associated with larger diameter capsules than was observed in the more suitable host chinook salmon 0 . tshawytscha. Awakura (1968) reported that glochidia of Margaritifera laenis were destroyed by host tissue proliferation in immature Oncorhynchus masou, Salvelinus leucomaenis, and Salmo gairdneri. Eosinophilia is a common tissue response in vertebrates to metazoan parasites. As in our study, Arey (1932a) and Fustish \& Millemann (1978) found fewer eosinophils in tissues surrounding glochidia in suitable than in unsuitable hosts.

The role of humoral factors between glochidia and the host is not clear. Meyers et al. (1980) demonstrated antibodies to Margaritifera margaritifera glochidia in plasma and mucus of both resistant and susceptible species of salmonids 8 to $12 \mathrm{wk}$ post-infection. In addition, in vitro survival times of glochidia were significantly shorter in the plasma of resistant fishes than in that of susceptible hosts. In contrast, Isom \& Hudson (1984) found that glochidia of 12 species of mussels of the Unionidae developed to juveniles in media containing plasma of several fishes, including that of reportedly resistant species. 
Host specificity of freshwater mussel glochidia probably depends on a number of factors that vary with both the species of mussel and host. Female mussels may release glochidia only in the presence of suitable hosts. Glochidia may attach only to certain fish species. They may attach and eventually be rejected by host tissue responses or fail to survive because host tissues lack vital nutrients. Complete encapsulation also seems to be essential for glochidial survival and development. Davenport \& Warmuth (1965) presented evidence that glochidia of Anodonta implicata do not discriminate in their initial attachment to fish gills. Presumably, host specificity in this species is the result of host rejection or incomplete encapsulation. Our findings indicated that host specificity in Lampsilis radiata siliquoidea depended on prolonged glochidial attachment, as well as on the encapsulation process and related host responses.

\section{LITERATURE CITED}

Arey, L. B. (1932a). A microscopical study of glochidial immunity. J. Morphol. 53: 367-379

Arey, L. B. (1932b). The formation and structure of the glochidial cyst. Biol. Bull. mar biol. Lab., Woods Hole 82: 212-221

Arey, L. B. (1932c). Certain basic principles of wound healing. Anat. Rec. 51: 299-313

Awakura, T (1968). The ecology of parasitic glochidia of the freshwater pearl mussel, Margaritifera laevis. Sci. Rep. Hokaido Fish Hatchery 23: 1-17

Cannon, M. S., Mollenhauser, H. H., Eurell, T E., Lewis, D. H.,
Cannon, A. M., Tompkins, C. (1980). An ultrastructural study of the leukocytes of the channel catfish, Ictalurus punctatus. J. Morphol. 164: 1-25

Davenport, D., Warmuth, M. (1965). Notes on the relationship between the freshwater mussel. Anodonta implicata and the alewife Pomolobus pseudoharengus. Limnol. Oceanogr 10: R74-R78

Ferguson, H. W. (1976). The ultrastructure of plaice (Pleuronectes platessa) leukocytes. J. Fish Biol. 8: 139-142

Fustish, C. A., Millemann, R. A. (1978). Glochidiosis of salmonid fishes. II Comparison of tissue response to coho and chinook salmon to experimental intection with Margaritifera margaritifera. J. Parasitol. 64: 155-157

Isom, B. G., Hudson, R. G. (1984). Freshwater mussels and their fish hosts: physiological aspects. J. Parasitol. 79: 318-319

Karna, D. W., Millemann, R. E. (1978). Glochidiosis of salmonid fishes. III. Comparative susceptibility to natural infection with Margaritifera margaritifera and associated histopathology. J. Parasitol. 64: 528-537

Laurent, P., Dunel, S. (1980). Morphology of gill epithelia. Am. J. Physiol. 238: R147-R159

Lefevre, G., Curtis, W. C. (1910). Reproduction and parasitism in the Unionidae. J. exp. Zool. 9: 78-115

Lester, R. J. G., Desser, S. S. (1975). Ultrastructural observations on the granulocytic leucocytes of the teleost Catostomus commersoni. Can. J. Zool. 53: 1648-1657

Meyers, T R., Millemann, R. E., Fustish, C. A. (1980). Glochidiosis of salmonid fishes. IV. Humoral and tissue responses of coho and chinook salmon to experimental infection with Margaritifera margaritifera. J. Parasitol. 66: $274-281$

Newstead, J. D. (1967). Fine structure of the respiratory lamellae of teleostean gills. Z. Zellforsch. 11. 396-428

Weinreb, E. L. (1963). Studies on the fine structure of teleost blood cells. I. Peripheral blood. Anat. Rec. 147: 219-225

Young, D. (1911). Implantation of the glochidium on the fish. Univ. Missouri Bull. Sci. Serv. 2: 1-16 